\title{
SEPSIS AND ACUTE KIDNEY INJURY: PATOPHYSIOLOGICAL MECHANISMS AND BASIC PRINCIPLES OF TREATMENT
}

\section{SEPSA I AKUTNO OŠTEĆENJE BUBREGA: PATOFIZIOLOŠKI MEHANIZMI I OSNOVNI PRINCIPI LEČENJA}

Saša Jaćović (1), Biserka Tirmenštajn Janković (2), Milenko Živanović (2), Dejan Petrović (3,5), Nedim Hamzagić (4) ,Petar Čanović (5), Biljana Popovska Jovičić (5,6), Željko Mijailović $(5,6)$

(1) MEDICINES AND MEDICAL DEVICES AGENCY OF SERBIA, BELGRADE, (2) DEPARTMENT OF NEPHROLOGY AND HEMODIALYSIS, HEALTH CENTER ZAJECAR, ZAJECAR, (3) CLINIC FOR UROLOGY, NEPHROLOGY AND DIALYSIS, CLINICAL CENTER KRAGUJEVAC, KRAGUJEVAC, (4) CENTER OF HEMODIALYSIS, MEDICAL CENTER TUTIN, TUTIN, (5) FACULTY OF MEDICAL SCIENCES, UNIVERSITY OF KRAGUJEVAC, KRAGUJEVAC, (6) CLINIC FOR INFECTIOUS DISEASES, CLINICAL CENTER KRAGUJEVAC, KRAGUJEVAC, SERBIA

Acknowledgments: Authors would like to express their gratitude to the Ministry of Education, Science and Technological Development of the Republic of Serbia for the Grant N0175014, from which the funds were used as one of the sources to financially support this paper.

Summary: Sepsis is the main cause of the development of acute kidney injury in critical ill patients in intensive care units. A reinforced and uncontrolled response of the host immune system to bacterial infection has a significant role in the pathogenesis of acute kidney injury in patients with sepsis. Early target therapy, early administration of antibiotics, optimal control of the site of infection, and kidney replacement therapy play a key role in the treatment of patients with sepsis. Continuous dialysis modalities are indicated in hemodynamically unstable patients with severe sepsis, septic shock and acute renal injury. Continuous veno-venous hemodiafiltration with the modified AN69ST membrane provides homeostasis of the immune system's response to bacterial infection, hemodynamic stability of the patient, improved kidney function and a higher survival rate for patients with septic shock and acute renal failure. Key words: sepsis,acute kidney damage,pathophysiological mechanisms, renal replacement therapy

Sažetak: Sepsa je glavni uzrok razvoja akutnog oštećenja bubrega kod kritičnih bolesnika u jedinicama intenzivne nege. Pojačani i nekontrolisani odgovor imunološkog sistema domaćinana bakterijske infekcije ima značajn uulogu u patogenezi akutnog oštećenja bubrega kod pacijenata sa sepsom. Ključnu ulogu u lečenju bolesnika s sepsomima rana ciljana terapija, rana primena antibiotika, optimalna kontrola mesta infekcije i terapija zamene renalne funkcije. Modaliteti kontinuiranog dijaliznog lečenja su indikovani kod hemodinamski nestabilnih bolesnika s teškom sepsom, septičkim šokom i akutnim oštećenjem bubrega. Kontinuiranaveno-venska hemodijafiltracija sa modifikovanom AN69ST membranom obezbedjuje homeostazu reakcije imunološkog sistema na bakterijske infekcije, hemodinamisku stabilnost bolesnika, poboljšanu funkciju bubrega i veću stopu preživljavanja kod pacijenata sa septičkim šokom i akutnom bubrežnom slabošću.

Ključne riječi: sepsa, akutno oštećenje bubrega, patofiziološki mehanizmi, terapija zamene bubrežne funkcije 


\section{INTRODUCTION}

Sepsis is the main cause of the development of acute kidney injury in critical ill patients in intensive care units (sepsis-induced acute kidney injury - SI-AKI) (responsible for 20-50\% of cases of acute kidney injury in these patients) [1-2]. The mortality rate of patients with septic shock and acute kidney injury is high and amounts to $50-80 \%$ [3]. Epidemiological studies show that 200000 patients die annually in the United States due to sepsis [4]. Critical ill patients in intensive care units with severe sepsis, septic shock and acute kidney failure require prolonged hospitalization, renal replacement therapy (RRT), increased treatment costs and have a high risk of insufficiency of other organs/systems and adverse outcomes. These patients require team approach, enhanced cooperation between anesthesiologists, infectologists and nephrologists. Early detection of sepsis and acute kidney injury, coupled with early target therapy, use of antibiotics and initiation of appropriate supportive therapy can correct the outcome of critical ill patients in intensive care units [5].

\section{Definition of sepsis}

Bacteraemia is defined as the presence of bacteria in the blood of patients. The patient's response to a bacterial infection (systemic inflammatory response syndrome -SIRS) is defined as the presence of $\geq 2$ of the following criteria: body temperature $>38,0^{\circ} \mathrm{C}$ or $<36,0^{\circ} \mathrm{C}$, heart rate $>90$ beats per minute, breathing frequency $>20$ respirations in minute or partial pressure of carbon dioxide - $\mathrm{pCO}_{2}<32 \mathrm{mmHg}$, the number of white blood cells $>12 \times 10^{9} / \mathrm{L}$ or $<4 \mathrm{x}$ $10^{9} / \mathrm{L}$ or the normal number of white blood cells with $>10 \%$ immature cell forms. Sepsis is defined as the systemic inflammatory response syndrome to proven infection caused by the bacteria, and severe sepsis as a sepsis associated with organ function disorder - SOFA score $\geq 2$ (sequential organ failure assessment - SOFA). Severe sepsis progresses to septic shock, which is defined as a persistent hypotension that does not repair after resuscitation of volume with $0.9 \% \mathrm{NaCl}$ solution of crystalloid at a dose of 40 $60 \mathrm{ml} / \mathrm{kg}$ of body mass in the first hour, requiring the use of vasopressor norepinephrine in a dose $>5 \mu \mathrm{g} / \mathrm{kg} / \mathrm{min}$ to maintain a mean arterial blood pressure-MAP $\geq 65 \mathrm{mmHg}$, associated with clinical data for hypoperfusion (serum lactate concentration greater than 2 $\mathrm{mmol} / \mathrm{l}$ ) and organ function disorder (SOFA score $\geq 2$ ). Refractory septic shock is defined as the need for norepinephrine at a dose> 15 $\mu \mathrm{g} / \mathrm{kg} / \mathrm{min}$ in order to achieve the target value of MAP $\geq 65 \mathrm{mmHg}$. In intensive care units, for detecting patients with suspected infection or proven infection and adverse outcome, a quick SOFA score (qSOFA) is used. Patients with qSOFA $\geq 2$ have the risk of prolonged hospital treatment and adverse outcome (altered state of consciousness: the Glasgow Coma Scale - GCS $<15$, breathing frequency $\geq 22$ respirations per minute, serum lactate concentration greater than $2 \mathrm{mmol} / \mathrm{l}$. In patients with sepsis, with qSOFA score $\geq 2$, a standard SOFA score should be made to detect organ function disorders [6]. Renal injury exists if serum creatinine concentration increases by more than 44.2 $\mu \mathrm{mol} / \mathrm{l}$ or $0.5 \mathrm{mg} / \mathrm{dl}$ compared to basal value, and urine output decreases below $0.5 \mathrm{ml} / \mathrm{kg} / \mathrm{h}$. A ratio of partial pressure of arterial oxygen to the fraction of inspired oxygen $-\mathrm{PaO}_{2} / \mathrm{FiO}_{2}$ ratio $<300$ indicates a lung function disorder, and GCSless than 15 for brain function disorder [67].

\section{Definition of acute kidney injury}

For the definition and assessment of the severity of acute kidney injury, clasifications RIFLE 2004(Risk, Injury, Failure, Loss, End-stage), as well as AKIN 2007(Acute Kidney Injury Network) and KDIGO 2012(Kidney Disease Improving Global Outcomes) are used. Based on the AKIN classification, acute kidney injury stage 1 is defined as an increase in serum creatinine by $\geq 26.5 \mu \mathrm{mol} / \mathrm{l} \quad(\geq 0.3 \mathrm{mg} / \mathrm{dl})$ or as an increase in serum creatinine concentration $\geq 1$.5times compared to basal creatinine in the serum in the previous 48 hours and/or as a urine output less than $0.5 \mathrm{ml} / \mathrm{kg} / \mathrm{h}$ for at least $6 \mathrm{~h}$. Based on the KDIGO classification, stage 1 of acute kidney injury is present in those patients who have a serum creatinine concentration of 1.5-1.9 times compared to basal, and urine output less than $0.5 \mathrm{ml} / \mathrm{kg}$ for $6-12 \mathrm{~h}$. The stage 2 of acute kidney injury is characterized by an increase in serum creatinine concentration of 2-2.9 times compared to basal and/or urine output less than $0.5 \mathrm{ml} / \mathrm{kg} / \mathrm{h}$ for $\geq 12 \mathrm{~h}$. The third stage of KDIGO classification of acute kidney injuries indicated either by increased serum creatinine 
concentration $\geq 3$ times within seven days, or increase in serum creatinine $\geq 354 \mu \mathrm{mol} / \mathrm{l} \quad(\geq 4$ $\mathrm{mg} / \mathrm{dl}$ ), with an acute increase of $0.5 \mathrm{mg} / \mathrm{dL}$ or initiation of RRT, and/or urine output $<0.3$ $\mathrm{ml} / \mathrm{kg} / \mathrm{h}$ for $24 \mathrm{~h}$, or anuria for $>12 \mathrm{~h}[8]$.

\section{INSUFFICIENCY OF ORGANS AND SYSTEMS IN SEPSIS}

\section{Acute damage and kidney impairment in sepsis}

Pathophysiological mechanisms of the development of acute kidney injury in patients with sepsis may be hemodynamic and nonhemodynamic. Hemodynamic pathophysiological mechanisms include: hypoperfusion of the kidneys, increased intraabdominal pressure, increased central venous pressure and blood stasis in the venous system of the kidneys. In the last decade, new nonhemodynamic pathophysiological mechanisms of the development of acute kidney injury in patients with sepsis have been discovered: the increased systemic and local responses of the host immune system to infection, increased production and secretion of proinflammatory mediators, "cytokine storm" (disturbance of the balance of proinflammatory and antiinflammatory cytokines in favour of proinflammatory), endothelial dysfunction of the kidney microvasculature, infiltration of renal parenchyma with immune system cells (monocytes / macrophages, neutrophils / leukocytes), activation of epithelial cells of proximal tubules through activation of Toll-like receptors - TLRs and oxidative stress (disorder of equilibrium of oxidative and antioxidative system in favour of oxidative) [9-11].

The enhanced and uncontrolled response of the host immune system to infection plays an important role in the development of acute kidney injury. Microorganisms and their products/molecular structures - pathogenassociated molecular patterns (PAMPs), such as lipopolysaccharide, lipoteichoic acid, flagellin, DNA of the bacteria are recognized by toll receptors [receptors that recognize molecular structures - pattern recognizing receptors (PRRs) on the surface of the immune system cells in the peripheral blood (monocytes/leukocytes)]. Activation of these receptors activates the cascade of signals that activate the transcription factors [(nuclear factor kappa B (NFkB), activator protein 1 (AP-1), interferon regulatory factor 3 (IRF3)], all of which results in increased formation and release of proinflammatory cytokines. TLRs are essential for the enhanced activation of the innate immune system of the host to infection caused by bacteria. The immune response of the host can be enhanced by molecules/molecular structures released from necrotic host cells damage-associated molecular patterns - DAMPs, such as chromatin-associated protein high mobility group box 1 - HMGB1 and heat shockproteins - HSP, histones and oxidatively altered lipoproteins - oxLDL. DAMPs molecules/molecular structures bind to TLR2/TLR4 on the surface of the cells of the innate immune system of the host in the peripheral blood (monocytes/leukocytes) and also stimulate the formation and release of proinflammatory mediators. The recognition of these endogenous molecules/molecular structures results in the development of "sterile inflammation", which contributes to the increased and uncontrolled response of the innate immune system of the host to the bacterial infection (a vicious circle develops). A key role in the development of acute kidney injury in patients with sepsis has the activation of epithelial cells of proximal tubules by PAPMs and DAMPs molecules/molecular structures. PAMPs and DAMPs molecules/molecular structures are filtered into glomeruli, reach to the lumen of proximal tubules, bind to and activate the toll-like receptors (TLR2/TLR4) expressed on the luminal surface of epithelial cells of proximal tubules. Previous studies have shown that the highest significance in the induction of acute kidney damage in patients with sepsis has the pathway of HMGB1-TLR4 signals (response of the local immune system of the kidney). Stimulated epithelial cells of proximal tubules increase the production and secretion of proinflammatory cytokines the response of the local immune system of the kidney enhances the response of the systemic immune system to the bacterial infection: a vicious circle develops) [9-11].Released proinflammatory cytokines from activated epithelial cells of proximal tubules and infiltrative cells (monocytes/macrophages, leukocytes) induce endothelial dysfunction, disorder of microcirculation of the kidney (peritubular capillary network), ischemia of 
epithelial cells of proximal tubules, oxidative stress, mitochondrial function disorder (reduced ATP production) and stop the growth of epithelial cells of proximal tubules in the G1 phase of mitosis. Two key factors involved in the stopping of growth of proximal epithelial cells are insulin-like growth factor binding protein 7 (IGFBP7) and tissue inhibitor of metalloproteinase 2 (TIMP-2). The results of the research performed so far show that the stopping of growth of epithelial cells of the proximal tubules plays a significant role in the development of acute kidney damage induced by sepsis [12-13]. Detection and clear definition of pathophysiological mechanisms of the development of acute kidney damage in patients with sepsis provides the possibility of developing new strategies for the treatment/protection of epithelial cells of proximal tubules [9-13].

\section{Acute damage and function disorder of the heart in sepsis}

Sepsis is an enhanced and uncontrolled response of the immune system of the host to infection, which results in acute damage and disorders of the function of several organs/system of organs, including sepsis-induced cardiomyopathy SICM. Cardiomyopathy induced by sepsis is defined as an ejection fraction of the left ventricle less than $50 \%$ or as a reduction in the ejection fraction $\geq 10 \%$ of the basal ejection fraction and the recovery of myocardial function in two weeks. Pathophysiological mechanisms of acute damage and function disorder of the heart in sepsis can be: hemodynamic (reduced blood flow through coronary arteries, myocardial ischemia, coronary microcirculation disorder and nonhemodynamic (inflammation and infiltration of the myocardial interstitiumby cells of innate immune system), oxidative stress, nitric oxide - NO, endothelial dysfunction, apoptosis and necrosis of cardiomyocytes. In sepsis, microorganisms release PAMPs molecules, such as lipopolysaccharide, lipoteichoic acid, flagellin, and DNA/RNA. These molecules/molecular structures are bound to specific receptors PRRs, such as TLRs on the surface of the cells of innate immune system of the host in the peripheral blood, but also on the surface of the cardiomyocytes. Receptors that recognize molecular structures - PRRs play a key role in enhancing the immune response of the host to the infection. DAMPs, molecules/molecular structures which are released from damaged cardiomyocytes, recognize and bind TLRs on the surface of cardiomyocytes (TLR2/TLR4), stimulate increased formation and release of proinflammatory cytokines (endothelial dysfunction, increased permeability of small blood vessels of myocardial interstitum, infiltration of myocardial interstitium with inflammatory cells, negative inotropic effect of proinflammatory mediators, cardiomyocyte mitochondrial function disorders, oxidative stress, apoptosis and necrosis of cardiomyocytes). All of this results in left ventricular dilatation with normal or low filling pressure, development of systolic heart failure (left ventricularejection fraction $-\mathrm{LVEF}<50 \%$ ) with normal or elevated stroke volume and cardiac index and with possible development of critical reduction in tissue perfusion(septic shock)[14]. Early application of antibiotics and surgical removal of the focus (early control of the site of infection) are crucial for the optimal treatment of patients with sepsis (they reduce the production of PAMPs molecules from bacteria). Optimization of the status of volemia and cardiac function is achieved by the use of crystalloid solution, norepinephrine, and in patients with cardiac index (CI) $<2.2 \mathrm{l} / \mathrm{min} / \mathrm{m}^{2}$ administration of levosimendan is indicated (increases the sensitivity of the myofibrils to calcium, improves left ventricular relaxation in the diastolic phase, does not increase the use of oxygen by cardiomyocytes and does not cause heart rhythm disturbances) [14-15].

\section{Acute damage and disorder of function of the liver in sepsis}

The incidence of acute damage and disorder of function of the liver in patients with sepsis ranges from $30-50 \%$. In patients with sepsis, two types of liver damage can develop: hypoxic hepatitis $(\mathrm{HH})$, and sepsis induced cholestasis (SIC). HH occurs as a consequence of septic shock due to reduced hepatic perfusion and decreased oxygen utilization by hepatocytes (due to the action of inflammatory mediators and endotoxins) and is characterized by centrilobular necrosis (CLN), a significant transient increase in aminotransferase concentration in the serum in the absence of another possible cause of necrosis of the liver 
cells. Clinically, it can also be demonstrated by acute liver failure. Another important pathophysiological mechanism of liver damage in patients with sepsis is cholestasis. The disorder of the bile salts transport occurs as a result of the reduced activity of the bile salt export pump (BSEP), which is located on the canalicular side of the liver cells. The decrease in activity is due to hypoperfusion, hypoxia, and disorder of mitochondrial function of the liver cells: lack of ATP. SIC is clinically manifested as a progressive increase in serum bilirubin concentrations (increase in total bilirubin at the expense of conjugated bilirubin) and jaundice. Due to intrahepatic cholestasis, decreased flow and bile inflow to the lumen of the gastrointestinal tract, there is an atrophy of the mucous membrane of the intestine, loss of bacteriostatic action, increased bacterial translocation and increased serum concentrations of endotoxins in these patients (enhancement of the systemic immune response of the host to bacterial infection) [16-17]. An important role in acute liver damage also has the enhanced response of the systemic and local immune system in the liver of the host to bacterial infection. PAMPS/DAMPs molecules/molecular structures, which bind to specific receptors - PRRs on the surface of the innate immune system cells (monocytes, leukocytes), but also toTLRs (TLR2-TLR6) of the liver and Kupffer cells, have a key role in the enhanced response of the immune system of the host and induction of the gene for the synthesis of proinflammatory cytokines, apoptosis and necrosis of the liver cells (acute liver failure, acutisation of chronic liver failure) [18]. The basic principles of treating acute liver damage in sepsis are early goal-directed therapy - EGDT, volume resuscitation, early antibiotic administration, infection site control, vasopressor support, and restoration of liver perfusion. Medicaments that have the potential to induce cholestasis and hepatocellular damage should be excluded [16-18]. An important role in the treatment of these patients also have thedifferent albumin dialysis modalities [16-18].

\section{Acute damage and disorder of the function of the lung in sepsis}

Acute respiratory distress syndrome (ARDS) is defined as an acute condition characterized by severe hypoxia, bilateral pulmonary infiltrates, and absence of evidence of cardiogenic pulmonary edema. An important role in the development of acute damage and lung function disorders (acute respiratory distress syndrome, non-cardiogenic pulmonary edema) has a reinforced and uncontrolled response of the systemic and local immune system to the bacterial infection. PAMPs and DAMPs molecules/molecular structures bind to TLRs on the surface of the innate immune system cells in the peripheral blood (monocytes/leukocytes), as well as on the surface of the epithelial and endothelial cells of the alveolo-capillary membrane of the lungs. After binding to TLRs on the target cells (HMGB1-TLR4), the transcription factor NFkB is activated, and the proinflammatory cytokines are increasingly produced and released. These mediators allow the accumulation of neutrophils and T-cells, apoptosis of epithelial and endothelial lung cells, and the development of non-cardiogenic pulmonary edema. The disease develops $12-48 \mathrm{~h}$ after the initial event, and is clinically manifested with a feeling of choking and severe hypoxia. The diagnosis of ARDS is based on four criteria: rapid onset, bilateral infiltrates on the chest radiograph, normal cardiac function (pulmonary capillary wedge pressure - PCWP) and $\mathrm{PaO}_{2} / \mathrm{FiO}_{2}$ ratio less than or equal to 200[19]. These patients are advised to lung protective ventilation strategy - LPVS, with low respiratory volume (tidal volume of $6 \mathrm{ml} / \mathrm{kg}$ of ideal body weight), whereby end-inspiratory plateau pressure should be less than $30 \mathrm{cmH}_{2} \mathrm{O}$ using the lowest positive end-expiratory pressure (PEEP = 5-10 cmH20) by which the satisfactory oxygenation is achieved $\left(\mathrm{PaO}_{2} 2=55-80 \mathrm{mmHg}\right.$ or $\mathrm{SaHbO}_{2}=88-90 \%$ ) [20-21]. In severe form of ARDS (severe hypoxemia:PaO2/FiO2 $<80 \mathrm{mmHg}$, uncompensated hypercapnia: $\mathrm{pH}<7.2$ ), the therapy for extracorporeal carbon dioxide removal - ECCO2R is indicated [22].

\section{Acute damage and disorder of the function of the brain in sepsis}

Sepsis-associated encephalopathy (SAE) is defined as a diffused brain function disorder that arises as a result of an increased and uncontrolled response of the host immune system to infection in the absence of a direct central nervous system infection. In the development of acute damage and brain function disorders, in patients with sepsis there are 
included three pathophysiologic pathways: the neuron/nerve pathway (activation of the afferent nerves, such as vagus and trigeminal nerves), the humoral pathway (cytokines in circulation) and the pathway of altered bloodbrain barrier (BBB). All three pathophysiologic pathways activate the microglial cells of the brain (the first detected change in SAE). Activated microglial cells of the brain enhance the production and secretion of nitric oxide, cytokines and free radicals - the reactive oxygen species(ROS), all of which results in the activation of endothelial cells and an increased BBB permeability (vicious circle), disorder of functions of microcirculation of the brain, reduced cholinergic function and altered neurotransmission, mitochondrial function disorder and brain cell apoptosis, development of acute damage and disorder of the function of the brain (encephalopathy associated with sepsis). Precipitating factors include metabolic disorders and use of medicaments. The main clinical features of acute encephalopathy caused by sepsis are: altered state of consciousness, cognitive disorder, cramping attacks and coma. The diagnosis of acute damage and disorder of the function of the brain is based on neurological examination and neurological tests, such as electroencephalography, transcranial Doppler ultrasound, computed tomography and nuclear magnetic resonance. Treatment of SAE consists of the application of early target therapy, early administration of antibiotics, optimal control of the site of infection and precipitating factors (metabolic disorders, use of medicaments) [23].

\section{Acute damage and disorder of coagulation in sepsis}

Disseminated intravascular coagulopathy occurs in $35 \%$ of patients with severe sepsis (sepsisinduced disseminated intravascular coagulation - SI-DIC). An initial step in the development of DIC in patients with sepsis is the increased accumulation of tissue factor (TF) on the surface of endothelial cells of small blood vessels. As part of the enhanced response of the immune system of the host to bacterial infection, PAMPs molecules/molecular structures of the bacteria (lipopolysaccharide, peptidoglycan) activate TLRs (TLR2/TLR4) on the surface of the immune system cells in the peripheral blood (monocytes, neutrophils). Activated neutrophils enhance the production and secretion of extracellular fibers consisting of DNA and numerous bactericidal proteins such asneutrophil extracellular traps (NETs), which are deposited on the surface of endothelial cells and initiate the process of immunotrombosis. Further, DAMPs such as HMGB1 and histones, release from the activated immune system cells and damaged tissue cells. These molecules activate TLRs on the surface of the endothelial cells, reduce the release of thrombomodulin (TM, anticoagulant effect), increase $\mathrm{TF}$ concentration (procoagulant effect), increase the formation and release of proinflammatory cytokines ("sterile inflammation"), stimulate platelet aggregation, lead to blood clots formation in small blood vessels and the development of DIC. TM is an endothelial anticoagulant factor: it stimulates the formation of activated protein C (APC), binds to HMGB1 and promotes its degradation by thrombin,so it prevents/blocks the binding of HMGB1 to the receptor for advanced glycation end products (RAGE) on the surface of endothelial cells. The TM/APC system plays a significant role in maintaining homeostasis of thrombosis and haemostasis, and in maintaining vascular integrity (prevents the development of DIC in patients with severe sepsis) [24-26]. Four clinical forms of DIC syndrome are distinguished: an asymptomatic form, a form with positive results without bleeding and/or thrombosis, a form with increased bleeding and a clinical form with increased thrombosis. The use of recombinant human APC (rhAPC)is associated with a high risk of bleeding. In clinical practice, for the treatment of DIC in patients with severe sepsis, antithrombin III is used (a loading dose of 6,000 IU/30 minutes followed by a continuous i.v. infusion of 6,000 IU/day for 4 days), rhAPC (administered in the form of a continuous i.v. infusion of $24 \mu \mathrm{g} / \mathrm{kg} / \mathrm{h}$ for 96h) and recombinant human soluble thrombomodulin (rTM). rTM is applied in patients with SI-DIC accompanied with one or morOorgan dysfunctions, wherein a value of the international normalized ratio (INR) is more than 1.4 , at a dose of $0.06 \mathrm{mg} / \mathrm{kg} /$ day for six days (i.v. infusion over 30 minutes/day, for six consecutive days) [24-27]. 


\section{DIAGNOSIS}

\section{Indicators of sepsis}

The number of leukocytes and serum C-reactive protein concentrations represent the "gold standard" for diagnosing the infection. Procalcitonin (PCT) concentration in serum is used to diagnose sepsis, make a decision for the use of antibiotics, and monitoring of the response to the applied antibiotic. The normal serum PCT concentration is less than $0.05 \mathrm{ng} / \mathrm{ml}$ (by some authors less than $0.1 \mathrm{ng} / \mathrm{ml}$ ). The serum PCT concentration below $0.5 \mathrm{ng} / \mathrm{ml}$ indicates local infection and inflammation, with a small risk of progression and severe sepsis (the concentration of PCT should be repeatedly checked over the interval of 6-24h). Sepsis is possible if the serum PCT concentration is 0.5$1.9 \mathrm{ng} / \mathrm{ml}$ (grey zone), and serum PCT concentration $\geq 2 \mathrm{ng} / \mathrm{ml}$ indicates sepsis. It considers that PCT elevation to $10 \mathrm{ng} / \mathrm{ml}$ indicates a severe sepsis, while level higher than $10 \mathrm{ng} / \mathrm{ml}$ is associated with the development of septic shock. In patients whose serum PCT concentration is $\geq 2 \mathrm{ng} / \mathrm{ml}$, therapy with antibiotics should be initiated immediately. The use of antibiotics should be discontinued when the concentration of PCT in the serum drops below $0.5 \mathrm{ng} / \mathrm{ml}$ [28-29].

\section{Indicators of acute damage and disorder of function of the kidnies}

In the last decade, a greater number of new indicators of acute kidney injury have been detected (indicators more sensitive compared to serum creatinine levels): urinary neutrophil gelatinase-associated lipocalin (uNGAL), urinary kidney injury molecule (uKIM-1), a liver-type fatty acid binding protein (L-FABP), urinary IL 18, TIMP-2, IGFBP-7 and cystatin C. The concentration of uNGAL> $150 \mathrm{ng} / \mathrm{ml}$ two hours after the initial event indicates the development of AKI. Significant role in the early detection of AKI have the growth factors of proximal tubule epithelial cells: TIMP-2 and IGFBP-7. The combination of TIMP-2 and IGFBP-7 in the urine showed good diagnostic performance in the early detection of the risk of developing acute renal failure within 12 hours. [TIMP-2]x[IGFBP7] $>0.3(\mathrm{ng} / \mathrm{mL}) 2 / 1000$ was superior for risk assessment of KDIGO stage 2 or 3 AKI when compared to simultaneously measured plasma and urine NGAL, plasma cystatin C, urine IL-18, KIM-1 and L-FABP [30-33].

\section{Indicators of acute damage and disorder of the function of the heart}

Cardiac troponins (cTnT/cTnI) are used to detect damage of myocardium caused by ischemia. An increase in troponin levels in serum of $\geq 20 \%$ compared to baseline indicates ischemic damage of cardiomyocytes, and values of $\geq 2 \mathrm{ng} / \mathrm{ml}$ indicate the development of acute myocardial infarction [34]. For the diagnosis of disorder of cardiac contractile function, natriuretic peptides (BNP, NT-proBNP) are used. In patients with endogenous creatinine clearance greater than $60 \mathrm{ml} / \mathrm{min} / 1.73 \mathrm{~m}_{2}$, heart failure exists if the serum BNP concentration is greater than $100 \mathrm{ng} / \mathrm{ml}$ and the concentration of NT-proBNP is greater than $400 \mathrm{pg} / \mathrm{ml}$. If the endogenous creatinine clearance is less than 60 $\mathrm{ml} / \mathrm{min} / 1.73 \mathrm{~m} 2$, the heart failure is indicated by a BNP concentration greater than $200 \mathrm{pg} / \mathrm{ml}$, or NT-proBNP greater than $1200 \mathrm{pg} / \mathrm{ml}$ [34].

\section{Indicators of acute damage and disorder of the function of the liver}

The most significant indicators of early liver damage are aminotransferases (ALT/AST), alkaline phosphatase (ALP), lactate dehydrogenase (LDH), gammaglutamyltranspeptidase (GGT), total bilirubin, albumin, and parameters of the blood coagulation system. For hepatocellular dysfunction, serum aminotransferases concentrations are measured, while cholestatic liver damage is defined by an increased concentration of ALP, conjugated bilirubin and GGT [35]. In HH, serum bilirubin concentration is normal or slightly increased, aminotransferase is increased up to 20 times from the upper normal limit, LDH is also increased (LDH > $5000 \mathrm{IU} / \mathrm{l}$ ), and the ALT/LDH ratio is less than 1.5 . Acute damage to the liver induced by medications (hepatocellular damage) indicates an increase in ALT for $\geq 5$ and the ratio ALT/ALP $\geq 5$. Cholestasis in patients with sepsis shows the total serum bilirubin concentration $\geq$ $2 \mathrm{mg} / \mathrm{dl}(\geq 34 \mu \mathrm{mol} / \mathrm{l}$ ) (increase of total bilirubin is at the expense of conjugated bilirubin), increased ALP $\geq 2$ times in relation to the upper normal limit and ALT/ALP ratio $\leq 2[35,36]$. 


\section{Indicators of acute damage and disorders of the function of the lung}

For early detection of acute lung injury in sepsis, gas analysis $(\mathrm{pH}, \mathrm{PaO} 2, \mathrm{PaCO} 2$ and $\mathrm{PaO} 2 / \mathrm{FiO} 2$ ratio, sometimes called the Carrico index)are used. For the definition and classification of severity of ARDS by $\mathrm{PaO} 2 / \mathrm{FiO} 2$ ratio, the Berlin Classification is used. This definition partitions patients into mild (PaO2/FiO2 200-300), moderate(PaO2/FiO2 100-199), and severe ARDS $(\mathrm{PaO} 2 / \mathrm{FiO} 2<100)$ and no longer includes the term "acute lung injury" [37].

\section{Indicators of acute damage and disorder of the function of the brain}

For early detection of acute damage and disorder of the function of the brain, a neuron specific enolase - NSE and S100 $\beta$ protein are used [38]. Studies have shown that S100 $\beta$ protein is a better indicator of acute damage and brain function disorders compared to NSE. The normal serum NSE concentration is $\leq 12.5$ $\mathrm{ng} / \mathrm{ml}$, and the serum protein $\mathrm{S} 100 \beta$ is less than $0.15 \mu \mathrm{g} / \mathrm{l}$. On the development of encephalopathy induced by sepsis indicate the NSE values $>24.15 \mathrm{ng} / \mathrm{ml}$ and $\mathrm{S} 100 \beta>0.15 \mu \mathrm{g} / \mathrm{l}$. Values of $S 100 \beta \geq 4 \mu \mathrm{g} / \mathrm{l}$ indicate a severe form of ischemic brain damage [38].

\section{Indicators of acute damage and disorders of the function of the coagulation system}

For early detection of DIC in patients with sepsis are used: platelet count, prothrombin time (PT), INR, activated partial thromboplastin time (aPTT), fibrin and fibrinogen-degradation products (FDP), concentration of D-dimer, APC, and serum TM. PT serves to evaluate the external pathway of activation of the coagulation system, and aPTT to assess the activation of the internal pathway of the coagulation system. Thrombocytopenia is an indicator of platelet aggregation induced by fibrin. An important role in homeostasis of thrombosis and hemostasis has a protein $\mathrm{C}$ system/activated protein $\mathrm{C}$. The normal concentration of activated protein $\mathrm{C}$ in the serum is $1-3 \mathrm{ng} / \mathrm{ml}$. Reduced platelet count $(<100 \times 109 / 1)$, increased INR $(\geq 1.2)$, prolonged PT $(\geq 3 \mathrm{~s})$, decreased fibrinogen $(<1 \mathrm{~g} / \mathrm{l})$, increased FDP $(\geq 10 \mu \mathrm{g} / \mathrm{ml})$, increased D-dimer (> $1 \mathrm{ng} / \mathrm{ml})$, decreased concentration of activated protein $\mathrm{C}(\mathrm{APC}<1 \mathrm{ng} / \mathrm{ml})$ and SIRS score $\geq 3$ indicate the development of DIC in patients with severe sepsis [39].

\section{PREVENTION AND TREATMENT}

\section{Prevention of acute damage and disorders of the function of the kidneys in sepsis}

Preventing the development of AKI include EGDT, early administration of antibiotics, and optimal control of the site of infection. Early target therapy involves resuscitation of volume using crystalloid solutions of $0.9 \% \mathrm{NaCl}$ at a dose of $20-40 \mathrm{ml} / \mathrm{kg}(2000 \mathrm{ml} 0.9 \% \mathrm{NaCl}$ sol. i.v. inf./60 minutes), during the first three hours of the development of septic shock (along with hemodynamic monitoring). Early target therapy should ensure optimal/adequate hemodynamic stability of patients: central venous pressure (CVP) of 8-12 $\mathrm{mmHg}, \mathrm{MAP} \geq 65 \mathrm{mmHg}$, urine output greater than $0.5 \mathrm{ml} / \mathrm{kg} / \mathrm{h}$ and central venous oxygen saturation $(\mathrm{ScvO} 2) \geq 70 \%$ in the first 6 hours from the development of septic shock. New recommendations indicate that targeted MAP in patients with septic shock should be $80-85 \mathrm{mmHg}$ (especially in patients who had high arterial blood pressure before the development of septic shock). If the target value of MAP is not achieved after resuscitation of volume with crystalloid solutions, norepinephrine (first-line vasopressor) is used, and in patients with $\mathrm{CI}<2.2 \mathrm{l} / \mathrm{min} / \mathrm{m} 2$, inotropic therapy (dobutamine, levosimendan). If hypotension is resistant to norepinephrine, vasopressin is administered at a dose of 0.01$0.03 \mathrm{IU} / \mathrm{min}$. Patients receiving norepinephrine at a dose of $5 \mu \mathrm{g} / \mathrm{min}$ can be added vasopressin at a dose of 0.01-0.03 IU/min. A broad spectrum antibiotic (vancomycin, beta-lactam antibiotics) should be administered within one hour from the development of septic shock, with presampling blood for the hemoculture. A loading dose of vancomycin is $25-30 \mathrm{mg} / \mathrm{kg}$, and it is applied for 7-10 days, and the target vancomycin concentration is $15-20 \mathrm{mg} / \mathrm{l}$. In addition to the use of antibiotics, control of the site of infection is important [40-47]. Early targeted therapy should ensure the restoration of effective arterial volume and perfusion of vital organs [46, 47]. 


\section{Treatment of acute damage and disorders of function of the kidneys caused by sepsis}

Critical ill patients in intensive care units with sepsis (severe sepsis/septic shock) and acute kidney injury require dialysis treatment (according to medical indications). Intermittent hemodialysis is a first-line therapeutic modality in hemodynamically stable patients with acute kidney injury for the treatment of hyperkalemia and life-threatening hypervolemia. Continuous dialysis modalities are indicated in hemodynamically unstable patients with acute kidney injuryassociated with severe sepsis/septic shock, as well as in patients with acute kidney injury associated with acute damage and impairment of the function of other organs (heart, brain, liver, lung). In patients with sepsis and acute kidney injury, the severity of AKI and the presence of absolute criteria for dialysis treatment should be assessed: resistant hyperkalemia $(\mathrm{K}+>6.5 \mathrm{mmol} / \mathrm{l}$ with or without electrocardiographic changes), resistant hypervolemia (furosemide resistant edema), severe metabolic acidosis ( $\mathrm{pH}$ of arterial blood $\leq$ 7.15), complications of high azotemia(uremic encephalopathy, uremic pericarditis) $[48,49]$.

In the absence of absolute criteria, treatment with dialysis should be started if severe AKIis diagnosed (stage AKIN3/KDIGO3), and in patients with severe sepsis and rapid deterioration of renal function treatment with dialysis should be initiated at stage 2 (AKIN2/KDIGO2) (modulation of response of the systemic and local immune system of the host on infection, clearanceof inflammatory mediators, PAMPs and DAMPs).Prior to making a decision to initiate treatment with dialysis in patients with sepsis and mild/moderate AKI (AKIN 1/2, KDIGO 1/2), treatment objectives should be considered: the severity of the clinical condition of the patient, renal functional reserve, the potential for complications, and clinical conditions that adversely affect the function of the kidneys. The clinical conditions that adversely affect the function of the kidneys are intra-abdominal hypertension and mechanical ventilation with positive ventilation pressure, and agentsthat have toxic effect on kidney tubules are nephrotoxic antibiotics and radiocontrast agents [50-52].

When indication for dialysis treatment is set, it is necessary to choose the appropriate dialysis modality, define the dialysis prescription (dialysis dose, duration, ultrafiltration, bleeding risk, anticoagulation type), patient monitoring, monitoring of extracorporeal circulation (ensuring survival of the hemodialysis filters) and evaluate the dose of dialysis delivered (percentage of delivered/achieved dose of dialysis in relation to the given dialysis dose). Intermittent hemodialysis is used in hemodynamically stable patients with hyperkalemia and hypervolemia that are lifethreatening for patients. Intermittent hemodialysis does not affect the clearance of inflammatory mediators (proinflammatory cytokines, antiinflammatory cytokines, PAMPs / DAMPs molecules/molecular structures). The dose of individual treatment of standard intermittent hemodialysis should be aimed to achieve Kt/V index $\geq 1.20$ [50-55]. Critically ill patients in intensive care units with severe sepsis/septic shock that are hemodynamically unstable with multiple organ systems failure, increased of serum concentrations ofinflammatory mediators (serum IL-6 $\geq 1000$ $\mathrm{pg} / \mathrm{ml}$ ), increased catabolism and hypervolemia require treatment with continuous modalities of dialysis: high-volume veno-venous hemofiltration (HVHF), continuous veno-venous hemodialysis with high cut-offmembranes (CVVHD-HCO), continuous veno-venous hemodiafiltration (CVVHDF) with polymethylmethacrylate (PMMA) and standard / modified acrylonitrile 69 surface-treated (AN69ST) membrane hemofilters [50-56]. HVHFcan be used as continuous with an ultrafiltration rate of $50-70 \mathrm{ml} / \mathrm{kg} / \mathrm{h}$ (35-80 $\mathrm{ml} / \mathrm{kg} / \mathrm{h}$ ) for 24 hours, or as a pulsed highvolume hemofiltration with a rate of ultrafiltration of $85-100 \mathrm{ml} / \mathrm{kg} / \mathrm{h} \quad(100-120$ $\mathrm{ml} / \mathrm{kg} / \mathrm{h}$ ) for 4-8 hours and then it can be proceeded with a standard dose of $35 \mathrm{ml} / \mathrm{kg} / \mathrm{h}$ [50-56].HVHF significantly reduces the concentration of inflammatory mediators and restores the balance of the proinflammatory and anti-inflammatory response of the immune system of the host to the bacterial infection [5056]. CVVHD-HCO appear to achieve greaterclearances of middle molecular weight solutes of 20-50 kDa [inflammatory mediators: IL1b (18 kDa), IL-6 (21 kDa), IL-10 (37 kDa); procalcitonin (13 kDa); myoglobin (17 kDa); $\beta 2$ microglobulin (12 kDa); Cystatin C (13 kDa); kappa free light chains $(25 \mathrm{kDa})]$ (the pore diameter $>0.01 \mu \mathrm{m}$, around double than a 
standard high-fluxmembrane). In clinical practice, two HCO membranes are used: polyarylethersulfone - septeX ${ }^{\circledR}$ and polysulfone - Enhanced Middle Molecule Clearance - EMiC®. CVVHD-HCO is used in patients with severe sepsis/septic shock and acute kidney damage (AKIN/KDIGO stage $\geq 1$ ) at a dose of $35 \mathrm{ml} / \mathrm{kg} / \mathrm{h}$ for 24 hours (increased risk of albumin loss 65 $\mathrm{kDa})$ and blockers ofanticoagulation: protein $\mathrm{C}$ (62 $\mathrm{kDa})$, protein $\mathrm{S}(69 \mathrm{kDa})$, antithrombin III (60 kDa) [57-59].

CVVHDFwith PMMA membrane, which has the ability to adsorb the inflammatory mediators (high capacity for cytokine adsorption), is administered at a dose of $35 \mathrm{ml} / \mathrm{kg} / \mathrm{h}$, in the course of $24-72 \mathrm{~h}$ and provides significantly hemodynamic stability and homeostasis of the host's systemic and local immune system responses to infection (prevents the development of "cytokine storm"). When the concentration of IL- 6 decreases below 1000 $\mathrm{pg} / \mathrm{ml}$, treatment is continued by standard CVVHDF with ultrafiltration of $35 \mathrm{ml} / \mathrm{kg} / \mathrm{h}$ [6062]. The standard AN69ST membrane is highly permeable, and binds heparin during the filling the extracorporeal circulation system with heparinized saline solution (during the preparation of the apparatus for the CVVHDFAN69ST treatment), has a high adsorption capacity for the inflammatory mediators (high adsorption capacity of HMGB1 proteins) and exhibits anti-thrombogenic effects (also referred to as an antithrombotic membrane, SepXiris $\left.{ }^{\circledR}\right)$. The modified AN69ST membrane is a surfacetreated polyacrylonitrile (AN69) hemofilter with a polyethyleneimine (PEI) layer, allowing for incorporation of a heparin layer by priming the membrane in a heparin-saline solution before CVVHDF, thereby significantlyreducing local thrombogenesis when compared with the original AN69 membrane. Also, heparin-primed AN69ST membranes are reportedly more biocompatible with advantages in terms of inflammatory cytokine adsorption.In patients with high risk of haemorrhage, venous anticoagulation is not required, and in patients with normal coagulation status for anticoagulation of extracorporeal circulation, unfractionated heparin is used in a dose of $50 \%$ less than the full dose [60-62]. Unfractionated heparin is used for anticoagulation of the extracorporeal circulation as a bolus of 2,000$5,000 \mathrm{IU}(30 \mathrm{IU} / \mathrm{kg}$ ) in the arterial segment of extracorporeal circulation after the blood-pump, and then continues with $5-10 \mathrm{IU} / \mathrm{kg} / \mathrm{h}$ (target aPTT $=45-55 \mathrm{~s}, 1.5-2$ times in relation to the upper normal limit in the blood sample before the filter).In patients with increased risk of haemorrhage (platelet count less than $60 \mathrm{x}$ 109/1, aPTT> 60s, INR> 2), the following options are applied: dialysis without heparin, predilution method of HDF, standard or modified AN69ST dialysis membrane, increased blood flow rate or regional citrate anticoagulation [6062]. In order to prevent the thrombosis of the filter, it is necessary to monitor the "vital signs" of the extracorporeal circulation: transmembrane pressure - TMP, pressure in the extracorporeal circulation after the blood pump and before the filter - Pin, pressure in the extracorporeal circulation segment after the filter - Pv, pressure gradient - $\Delta \mathrm{P}$ or "drop" pressure (reduction of pressure that occurs when blood is passing through the filter, calculated as $\Delta \mathrm{P}=\mathrm{Pin}-\mathrm{Pv}$ ). $\mathrm{TMP}>250 \mathrm{mmHg}$, Pin $>200 \mathrm{mmHg}$ and $\Delta \mathrm{P}>26 \mathrm{mmHg}$ indicate an increased risk of thrombosis of the filter [63]. For evaluation of the efficiency of AN69ST membrane, serial measurement of urea concentration in effluent and blood of patients FUN/BUN (measurement at every $12 \mathrm{~h}$ ) is used. The filter is effective if the FUN/BUN ratio is $\geq$ 0.8 , and values less than 0.8 indicate the risk of thrombosis of the filter. For the assessment of the dialysis dose of continuous renal replacement therapy, the ratio of delivered and prescribed dose is calculated (intensity method). CVVHDF is effective if the ratio of delivered and prescribed dialysis is $\geq 80 \%$ (the effective treatment time should be $\geq 20 \mathrm{~h}$ ) [64].

\section{Recovery of renal function}

The degree of recovery ofrenal function after acute damage affects the long-term outcome of the kidney functions and patient's condition. One of the goals of treating patients with sepsis and acute kidney injury is to achieve a maximum recovery of renal function. Recovery of renal function in patients with acute kidney injury may occur within the first seven days after initial kidney damage (early recovery). Early recovery of renal function depends on the severity of acute kidney injury, the duration of the acute kidney injury episode, the patient's hemodynamic stability and the functional reserve of the kidneys. Late recovery of renal function can occur in the stage of acute kidney 
disease, within a time period of 7-90 days after initial kidney injury[acute kidney disease describes acute or subacute damage and/or loss of kidney function for a duration of between 7 and 90 days after exposure to an acute kidney injury initiating event]. Chronic kidney disease is defined by the persistence of kidney disease for a period of $>90$ days $[65,66]$.

Renal function reserve (RFR) describes the capacity of the kidney to increase glomerular filtration rate (GFR) in response to physiological or pathological stimuli. Kidney stress tests are used for the evaluation of RFR (stress tests for the assessment of glomerular and tubular kidney function). In patients with acute kidney injury, a furosemide stress test is used to evaluate RFR. In critical ill patients in intensive care units, with acute kidney injury KDIGO stage 1 or stage 2, furosemide is applied intravenous in a dose of 1$1.5 \mathrm{mg} / \mathrm{kg}(1.5 \mathrm{mg} / \mathrm{kg}$ in patients who had previously received furosemide) and diuresis is monitored for the next two hours. The response to furosemide is appropriate if the urine output is $\geq 200 \mathrm{ml} / 2 \mathrm{~h}$. If an appropriate response is not achieved, this indicates the progression of acute kidney injury, the transition of acute kidney injury from KDIGO2 to KDIGO 3 stage (within 14 days) and the need for dialysis treatment. Stress test with furosemide can also be used to evaluate the end of treatment of AKI with continuous dialysis modalities. After completing the treatment of a continuous dialysis modality, diuresis is monitored during the period of $4 \mathrm{~h} /$ first-four-period. A good response is defined as the urine output $>400 \mathrm{ml} / 4 \mathrm{~h}$. After thefirst four-hour period, continuous intravenous infusion of furosemide of $0.5 \mathrm{mg} / \mathrm{kg} / \mathrm{h}$ is included for $4 \mathrm{~h}$. After 24 hours from the end of intravenous infusion of furosemide, the diuresis is monitored in a new four-hour period and compared with diuresis from the first four-hour period.Urine output greater than $400 \mathrm{ml} / 4 \mathrm{~h}$ and clearance of endogenous creatinine calculated from the volume of urine collected over 4 hours greater than $30 \mathrm{ml} / \mathrm{min}$ indicate the absence of need for further dialysis treatment [66-69].

LITERATURE:

1. Singbartl K, Kellum JA. AKI in the ICU: definition, epidemiology, risk stratification, and outcomes. Kidney Int 2012; 81(9): 819-25.

2. Ostermann M, Joannidis M. Acute Kidney Injury 2016: diagnosis and diagnostics workup. Crit Care 2016; 20(1): 299-312.

3. Martensson J, Bellomo R. Sepsis-Induced Acute Kidney Injury. Crit Care Clin 2015; 31(4): 649-60.

\section{CONCLUSIONS}

Sepsis is a common cause of developing acute kidney injury in critical ill patients in intensive care units. A significant role in the development of acute kidney injury in patients with sepsis (severe sepsis/septic shock) has a reinforced and uncontrolled response of the systemic and local immune system to the bacterial infection. ("cytokine storm"). PAMP molecules/molecular structures activate TLRs on the surface of the innate immune system cells (monocytes and neutrophils) in systemic circulation. DAMP molecules activate TLRs on the surface of the epithelial cells of proximal tubules and stimulate the formation of proinflammatory mediators ("sterile inflammation"), which additionally enhances the response of the immune system of the host (vicious circle). Early targeted therapy, early antibiotic administration, and optimal control of the site of infection have a key role in treating patients with sepsis. CVVHDF with AN69ST membrane statistically significantly reduces the concentration of inflammatory mediators as well as PAMP and DAMP molecules in serum of patients with severe sepsis, septic shock and acute kidney injury. It is administered at a dose of $35 \mathrm{ml} / \mathrm{kg} / \mathrm{h}$ for three consecutive days. When the concentration of IL- 6 is reduced below $1000 \mathrm{pg} / \mathrm{ml}$, the treatment should continue with standard CVVHDFin accordance with medical indications. The dialysis is effective if the FUN/BUN ratio is $\geq 0.8$ and the ratio of the delivered and prescribed dose of dialysis $\geq 80 \%$. Early sepsis detection, enhanced co-operation of anesthesiologist, infectologist and nephrologist, early target therapy, early antibiotic treatment and early dialysis therapy (continuous venovenous hemodiafiltration with modified AN69ST membrane) provide a greater degree of recovery of renal function and better outcome for patients with sepsis and acute kidney injury.

4. Swaminathan S, Rosner MH, Okusa MD. Emerging Therapeutic Targets of Sepsis-Associated Acute Kidney Injury. SeminNephrol 2015; 35(1): 38-54.

5. Rizo-Topete L, Ronco C. Critical Care Nephrology: A Multidisciplinary Approach. Blood Purif 2017; 43: 53-6.

6. Singer M, Deutschman CS, Seymour CW, Shankar-Hari M, Annane D, Bauer $\mathrm{M}$, et al. The Third International Consensus Definitions for Sepsis and Septic Shock (Sepsis-3). JAMA 2016; 315(8): 801-10.

7. Angus DC, Van der Pol T. Severe Sepsis and Septic Shock. N Engl J Med 2013; 369(9): 840-51. 
8. KDIGO Clinical Practice Guideline for Acute Kidney Injury. AKI Definition. Kidney IntSuppl 2012; 2(1): 1936.

9. Zarbock A, Gomez H, Kellum JA. Sepsis-induced AKI revisited: pathophysiology, prevention and future therapies. CurrOpinCrit Care 2014; 20(6): 588-95.

10. Gomez H, Ince C, Backer DD, Pickkers P, Payen D, Hotchkiss J, Kellum JA. A Unified Theory of SepsisInduced Acute Kidney Injury: Inflammation, microcirculation dysfunction, bioenergetics and the tubular cell adaptation to injury. Shock 2014; 41(1): 3 11.

11. Doi K. Role of kidney injury in sepsis. J Intensive Care 2016; 4: 17. DOI: 10.1186/s40560-016-0146-3.

12. Kellum JA, Chawla LS. Cell-cycle arrest and acute kideny injury: the light and the dark side. Nephrol Dial Transplant 2016; 31(1): 16-22.

13. Lameire N, Vanmassenhove, Van Biesen W, Vanholder R. The cell cycle biomarkers: promising research, but do not oversell them. Clin Kidney J 2016; 9(3): 353-8.

14. Kakihana Y, Ito T, Nakahara M, Yamaguchi K, Yasuda T. Sepsis-induced myocardial dysfunction: pathophysiology and management. J Intensive Care 2016; 4: 22. DOI: 10.1186/s40560-016-0148-1.

15. Sato $R$, Nasu M. A review of sepsis-induced cardiomyopathy. J Intensive Car 2015; 3: 48. DOI: 10.1186/s40560-015-0112-5.

16. Yan J, Li S, Li S. The role of the liver in sepsis. Int Rev Immunol 2014; 33(6): 498-510.

17. Henrion J. Hypoxic hepatitis. Liver Int 2012; 32(7): 1039-52.

18. Arroyo V, Moreau R, Jalan R, Gines P, EASL-CLIF Consortium CANONIC Study. Acute-on-chronic liver failure: A new syndrome that will re-classify cirrhosis. J Hepatol 2015; 62(Suppl 1): 131-43.

19. Faubel S, Edelstein CL. Mechanisms and mediators of lung injury after acute kidney injury. Nat Rev Nephrol 2016; 12(1): 48-60.

20. Koyner JL, Murray PT. Mechanical Ventilation and LungKidney Interactions. Clin J Am Soc Nephrol 2008; 3(2): 562-70.

21. Koyner JL, Murray P. Mechanical Ventilation and the Kidney. Blood Purif 2010; 29(1): 52-6.

22. Romagnoli S, Ricci Z, Ronco C. Novel Extracorporeal Therapies for Combined Renal-Pulmonary Dysfunction. SeminNephrol 2016; 36(1): 71-7.

23. Sonneville R, Verdonk F, Rauturier C, Klein IF, Wolff M, Annane D, et al. Understanding brain dysfunction in sepsis. Ann Intensive Care 2013; 3: 15. DOI: 10.1186/2110-5820-3-15.

24. Okamoto K, Tamura T, Sawatsubashi Y. Sepsis and disseminated intravascular coagulation. J Intensive Care 2016; 4: 23. DOI: 10.1186/s40560-016-0149-0.

25. Ikezoe $\mathrm{T}$. Thrombomodulin/activated protein $\mathrm{C}$ system in septic disseminated intravascular coagulation. J Intensive Care 2015; 3(1): 1. DOI: 10.1186s40560-0140050-7.

26. Ito T. PAMPs and DAMPs as triggers for DIC. J Intensive Care 2014; 2: 65. DOI: 10.1186/s40560-014-0065-0.

27. Yamato M, Minematsu Y, Fujii J, Mori K, Minato T, Miyagawa $S$, et al. Effective Combination Therapy of Polymixin-B Direct Hemoperfusion and Recombinant Thrombomodulin for Septic Shock Accompanied by Disseminated Intravascular Coagulation: A Historical Controlled Trial. TherApher Dial 2013; 17(5): 472-6.

28. Vijayan AL, Ravindran S, Saikant R, Lakshmi S, Kartik R, Manoj G. Procalcitonin: a promising diagnostic marker for sepsis and antibiotic therapy. J Intensive Care 2017; 5: 51. DOI: 10.1186/s40560-017-0246-8.

29. Carr JA. Procalcitonin-guided antibiotic therapy for septic patients in the surgical intensive care unit. J Intensive Care 2015; 3: 36. DOI: 10.1186/s40560-0150100-9.

30. Parikh CR, Moledina DG, Coca SG, Thiessen-Philbrook HR, Garg AX.Application of new acute kidney injury biomarkers in human randomized controlled trials.Kidney Int 2016; 89: 1372-9.

31. Chindarkar NS, Chawla L, Straseski JA, Jortani SA, Uettwiller-Geiger D, Orr RR, et al. Reference interval of urinary acute kidney injury (AKI) markers [IGFBP7]x[TIMP2] in apparently healthly subjects and chronic comorbid subjects without AKI. ClinChimActa 2016; 452(1): 32-7.

32. Vijayan A, Faubel S, Askenazi DJ, Cerda J,Fissell WH, Heung $M$, et al. Clinical Use of the Urine Biomarker [TIMP-2] x [IGFBP7] for Acute Kidney Injury Risk Assessment. Am J Kidney Dis 2016; 68(1): 19-28.

33. Sato E, Kamijo-Ikemori A, Oikawa T, Okuda A, Sugaya T, Kimura K, et al. Urinary excretion of liver-type fatty acidbinding protein reflects the severity of sepsis. Renal Replacement Therapy 2017; 3: 26. DOI: 10.1186/s41100-017-0107-x.

34. Maisel AS, Katz N, Hillege HL, Shaw A, Zanco P, Bellomo $\mathrm{R}$, et al. Biomarkers in kidney and heart disease. Nephrol Dial Transplant 2011; 26(1): 62-74.

35. Lescot T, Karvellas C, Beaussier M, Magder S. Acquired Liver Injury in the Intensive Care Units. Anesthesiology 2012; 117(4): 898-904

36. Kullak-Ublick GA, Andrade RJ, Merz M, End P, Benesic A, Gerbes AL, et al. Drug-induced liver injury: recent advances in diagnosis and risk assessment. Gut 2017; 66(6): 1154-64.

37. Seeley EJ. Updates in the Management of Acute Lung Injury: A Focus on the Overlap Between AKI and ARDS. Adv Chronic Kidney Dis 2013; 20(1): 14-20.

38. Yao B, Zhang LN, Liu ZY, Huang L. Serum S100 $\beta$ is a better biomarker than neuron-specific enolase for sepsis-associated encephalopathy and determining its prognosis: a prospective and observational study. Neurochem Res 2014; 39(7): 1263-9.

39. Ishikura $H$, Nishida $T$, Murai A, Nakamura $Y$, Irie $Y$, Tanaka J, et al. New diagnostic strategy for sepsisinduced disseminated intravascular coagulation: a prospective single-center observational study. Crit Care 2014; 18(1): R19. DOI: 10.1186/cc13700.

40. Rivers E, Nguyen B, Havstad S, Ressler J, Muzzin A, Knoblich B, et al. Early Goal-Directed Therapy in the Treatment of Severe Sepsis and Septic Shock. N Engl J Med 2001; 345(19): 1368-77.

41. Otero RM, Nguyen HB, Haung DT, Gaieski DF, Goyal M, Gunnerson KJ, et al. Early Goal-Directed Therapy in Severe Sepsis and Septic Shock Revisited. Chest 2006; 130(5): 1579-95

42. Venkataraman R, Kellum JA. Sepsis: Update in the Management. Adv Chronic Kidney Dis 2013; 20(1): 6-13.

43. Honore PM, Jacobs R, Hendrickx I, Bagshaw SM,JoannesBoyau 0 , Boer $W$, et al. Prevention and treatment of sepsis-induced acute kidney injury: an update. Ann Intensive Care 2015; 5: 51. DOI: 10.1186/s13613-0150095-3.

44. Rhodes A, Evans LE, Alhazzani W, Levy MM, Antonelli M, Ferrer R, et al. Surviving Sepsis Campaign: International Guidelines for Management of Sepsis and Septic Shock: 2016. Intensive Care Med 2017; 43: 304-77. DOI: 10.1007/s00134-017-4683-6. 
45. Joannidis M, Druml W, Forni LG, Honore GPM, Hoste E, Ostermann $\mathrm{M}$, et al. Prevention of acute kidney injury and protection of renal function in the intensive care unit: update 2017. Intensive Care Med 2017; 43(6): 73049.

46. Petrović D. Akutnooštećenjebubrega: etiologija, dijagnostikailečenje.MedicinskaIstraživanja 2011;45(3):7-13.

47. Petrović D, Mijailović Ž, Popovska B, Miloradović V, Đurđević P. Sepsis and cardiorenal syndrome: etiopathogenesis, diagnosis and treatment. Ser J Exp Clin Res 2013; 14(4): 181-7.

48. Palevsky PM. Renal Replacement Therapy in Acute Kidney Injury. Adv Chronic Kidney Dis 2013; 20(1): 7684.

49. Heung M, Yessayan L. Renal Replacement Therapy in Acute Kidney Injury: Controversies and Consensus. Crit Care Clin 2017; 33(2): 365-78.

50. Bagshaw SM, Cruz DN, Gibney RTN, Ronco C. A proposed algorithm for initiation of renal replacement therapy in adult critically ill patients. Crit Care 2009; 13(6): 317-25

51. Wald R, Bagshaw SM. The Timing of Renal Replacement Therapy Initiation in Acute Kidney Injury. SeminNephrol 2016; 36(1): 78-84

52. Shiao CC, Huang TM, Spapen HD, Honore PM, Wu VC. Optimal timing of renal replacement therapy initiation in acute kidney injury: the elephant felt by the blidmen? Crit Care 2017; 21: 146. DOI: 10.1186/s13054-0171713-2.

53. Bagshaw SM, Wald R. Strategies for the optimal timing to start renal replacement therapy in critically ill patients with acute kidney injury. Kidney Int 2017; 91(2): 102232.

54. Murugan R, Hoste E, Mehta RL, Samoni S, Ding X, Rosner $\mathrm{MH}$, et al. Precision Fluid Management in Continuous Renal Replacement Therapy. BlodPurif 2016; 42(3): 266-78.

55. Macedo E, Mehta RL. Continous Dialysis Therapies: Cor Curriculum 2016. Am J Kidney Dis 2016; 68(4): 645-57.

56. Rimmele T, Kellum JA. Clinical review: Blood purification for sepsis. Crit Care 2011; 15(1): 205. DOI: $10.1186 /$ cc9411.

57. Villa G, Zaragoza JJ, Sharma A, Neri M, De Gaudio AR, Ronco C. Cytokine Removal with High Cut-Off Membrane: Review of Literature. Blood Purif 2014; 38(3-4): 167-73.

58. Gondouin B, Hutchison CA. High-Cut-off Dialysis Membranes: Current Uses and Future Potential. Adv Chronic Kidney Dis 2011; 18(3): 180-7.

\section{LIST OF ABBREVIATIONS}

AKI - Acute Kidney Injury

AKIN - AKI Network

AN69ST - Polyacrylonitrile (surface treated)

AP-1 - Activator Protein 1

APC - Activated Protein C

ARDS - Acute Respiratory Distress Syndrome

BBB - Blood-Brain Barrier

BESP - Bile Salt Export Pump

$\mathrm{CI}$ - Cardiac Index

CLN - Centrilobular Cell Necrosis

CVVHDF - Continuous Veno-Venous Hemodiafiltration

CVVHD-HCO - Continuous Veno-Venous High - Cut-Off

Hemodialysis

DAMPs - Damage-Associated Molecular Patterns

DIC - Disseminated Intravascular Coagulopathy

LVEF - Left Ventricular Ejection Fraction

ECCO2R - Extracorporeal Carbon Dioxide Removal
59. Villa G, Chelazzi C, Morettini E, Zamidei L, Valente S, Caldini $\mathrm{AL}$, et al. Organ dysfunction during continuous veno-venous high cutt-off hemodialysis in patients with septic acute kidney injury. A prospective observational study. PLoSOne 2017; 12(2): e0172039.

60. Oda S, Aibiki M, Ikeda T, Imaizumi H, Endo S, Ochai R, et al. The Japanese guidelines for the management of sepsis. J Intensive Care 2014; 2: 55 . DOI: 10.1186/s40560-014-0055-2.

61. Hattori N, Oda S. Cytokine-adsorbing hemofilter: old but new modality for septic acute kidney injury. Renal Replacement Therapy 2016; 2: 41. (DOI: 10.1186/s41100-016-0051-1.Tanaka A, Inaguma D, Nakamura T, Watanabe T, Ito E, Kamegai N, et al. Effect of continuous hemodiafiltration using an AN69ST membrane in patients with sepsis. Renal Replacement Therapy 2017; 3: 12. (DOI: 10.1186/s41100-0170093z).

62. Baldwin I, Fealy N. Clinical Nursing for the Application of Continuous Renal Replacement Therapy in the Intensive Care Unit. Semin Dial 2009; 22(2): 189-93.

63. Bagshaw SM, Chakravarthi MR, Ricci Z, Tolwani A, Neri $M$, De Rosa $S$, et al Precision Continuous Renal Replacement Therapy and Solute Control. Blood Purif 2016; 42(3): 238-47.

64. Forni LG, Darmon M, Ostermann M, Oudemans-van Straaten HM, Pettila V, Prowle JR, et al. Renal Recovery after acute kidney injury. Intensive Care Med 2017; 43(6): 855-66.

65. Chawla LS, Bellomo R, Bihorac A, Goldstein SL, Siew ED, Bagshow SM, et al. Acute kidney disease and renal recovery: consensus report of the Acute Disease Quality Initiative (ADQI) 16 Workgroup. Nat Rev Nephrol 2017; 13(4): 241-57.

66. Chawla LS, Ronco C. Renal Stress Testing in the Assessment of Kidney Disease. KI Reports 2016; 1(1): 57-63.

67. Koyner JL, Davison DL, Brasha-Mitchell E, Chalikonda DM, Arthur JM, Shaw AD, et al. Furosemide Stress Test and Biomarkers for the Prediction of AKI Severity. J Am SocNephrol 2015; 26(8): 2023-31.

68. Ostermann M, Joannidis M, Pani A, Floris M, De Rosa S, Ronco C. Patients Selection and Timing of Continuous Renal Replacement Therapy. Blood Purif 2016; 42(3): 224-37.

EGDT - Early Goal-Directed Therapy

GCS - Glasgow Coma Score

GFR - Glomerular Filtration Rate

HH - Hypoxic Hepatitis

HMGB1 - High-Mobility Group Box 1

HSP - Heat Shock Proteins

HVHF - High-Volume Hemofiltration

IGFBP-7 - Insulin-Like Growth Factor Binding Protein-7

INR - International Normalized Ratio

IRF3 - Interferon-Regular Factor 3

KDIGO - Kidney Disease Improving Global Outcomes

KIM-1 - Kidney Injury Molecule

L-FABP - Liver-type Fatty Acid-Binding Protein

LPVS - Lung Protective Ventilation Strategy

MAP - Mean Arterial Pressure

NETs - Neutrophil Extracellular Traps

NFkB - Nuclear Factor kB

NGAL - Neutrophil Gelatinase-Associated Lipocalin 
PAMPs - Pathogen-Associated Molecular Patterns

$\mathrm{PaO} 2 / \mathrm{FiO} 2$ - A ratio of partial pressure of arterial oxygen to

the fraction of inspired oxygen

PCT - Procalcitonin

PCWP - Pulmonary Capillary Wedge Pressure

PEEP - Positive End-Expiratory Pressure

PMMA - Polymethylmethacrylate

PRRs - Pattern Recognition Receptors

RAGE - Receptor for Advanced Glycation End products

RFR - Renal Function Reserve

RIFLE - Risk, Injury, Failure, Loss, End-stage

ROS - Reactive Oxygen Species

RRT - Renal Replacement Therapy

SAE - Sepsis Associated Encephalopathy

SI-AKI - Sepsis Induced Acute Kidney Injury

SIC - Sepsis Induced Cholestasis

SICM - Sepsis-Induced Cardiomyopathy

SIRS - Systemic Inflammatory Response Syndrome

SOFA - Sequential Organ Failure Assessment

TF - Tissue Factor

TIMP-2 - Tissue Inhibitor of Metalloproteinases-2

TLRs - Toll-Like Receptors

TM - Thrombomodulin 